\title{
INFLUÊNCIA DE AGREGADOS RECICLADOS DE RESÍDUOS DE CONSTRUÇÃO NAS PROPRIEDADES MECÂNICAS DO CONCRETO
}

\author{
Influence of recycled aggregates from construction waste on mechanical \\ properties of concrete
}

\section{Daniel de Lima Araújo ${ }^{1}$, Ludmylla Pires Felix ${ }^{2}$, Leonardo Costa e Silva ${ }^{3}$, Thiago Martins dos Santos ${ }^{4}$}

Recebido em 05 de julho de 2015; recebido para revisão em 08 de outubro de 2015; aceito em 19 de novembro de 2015; disponivel on-line em 08 de fevereiro de 2016.

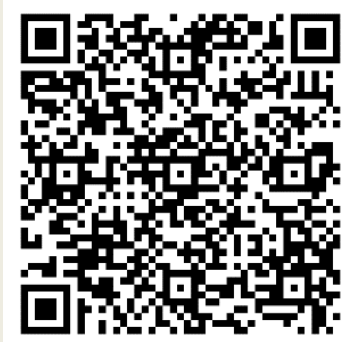

PALAVRAS CHAVE:

Concreto estrutural;

Agregados reciclados;

Resíduos de construção

\section{KEYWORDS:}

Structural concrete;

Recycled aggregates;

Construction waste.

* Contato com os autores:

${ }^{1}$ e-mail : dlaraujo@ufg.br (D. L. Araújo )

Engenheiro Civil, Doutor, Professor Associado, Escola de Engenharia Civil e Ambiental, Universidade Federal de Goiás, Goiânia, GO.

${ }^{2}$ e-mail : piresfelix@gmail.com ( L. P. Felix )

Engenheira Civil. Lyon Engenharia Ltda., Goiânia, GO.

${ }^{3}$ e-mail : costaesilvaleonardo@gmail.com ( L. C. Silva )

Engenheiro Civil. Gonzaga \& Costa Construtora, Goiânia, GO.

${ }^{4}$ e-mail : thiagogremal@gmail.com_ (T. M. Santos )

Engenheiro Civil, Banco do Brasil, Goiânia - GO.

ISSN: 2179-0612 D.0.I. 10.5216/reec.V11i1.35467

RESUMO: É notório o desperdício de materiais na construção civil, o que resulta na de resíduos de construção. Com a normalização ambiental recente, não se acequada ou, sempre que possível, buscar formado por concreto e argamassa, denominados de resíduos "cinzas". Assim, este trabalho tem como objetivo analisar a substituição dos agregados graúdos naturais por agregados graúdos oriundos da reciclagem de resíduos "cinzas" da construção. Para isso, foram analisados traços de concreto contendo vários níveis de substituição $19 \%, 43 \%, 75 \%, 100 \%)$ do agregado natural pelo agregado reciclado. Fo ada a influência dos agregados reciclados em algumas propriedades do estados fresco e endurecido, com destaque para a resistência à substituição de até $100 \%$ do agregado natural pelo agregado reciclado sem prejuízo da resistência mecânica do concreto e com redução de apenas $12 \%$ no módulo de elasticidade, o que indica a possibilidade do mesmo ser utilizado na produção de

ABSTRACT: The material loss in civil construction is large, which results in a great amount of construction waste. The latest environmental standards in Brazil do not are indiscriminately disposed of, and it is necessary to ensure their concrete and mortar, called "grey waste". The natural aggregates with coarse recycled aggregates to evaluate the influence of this substitution on the fresh and mechanical properties of the concrete. The most important mechanical properties analyzed are the compressive strength and modulus of elasticity. The results show that it is possible to replace up to $100 \%$ of tural aggregate with recycled aggregates without reducing the compressive strength. In this case, the modulus of elasticity is reduced by only $12 \%$. This suggests that recycled aggregates can be used in the production of structural concretes.

C 2016 REEC - Todos os direitos reservados. 


\section{INTRODUÇÃO}

O ambiente da construção civil, principalmente no Brasil, está relacionado ao desperdício de materiais, muitas vezes devido à falta de medidas de reaproveitamento de resíduos. Estudos demonstram que $40 \%$ a $70 \%$ da massa dos resíduos urbanos são gerados em canteiros de obras (PINTO, 1999; BLUMENSCHEIN, 2007). O custo e a falta de locais adequados para descarte desses materiais são fatores que deveriam despertar interesse nas empresas em promover e patrocinar pesquisas em reciclagem de Resíduos de Construção e Demolição (RCD).

A destinação inadequada dos resíduos oriundos do processo construtivo gera problemas como o esgotamento de aterros sanitários (esses resíduos chegam a mais de $50 \%$ do volume de resíduos depositados em aterros), a obstrução do sistema de drenagem urbana e a proliferação de insetos e roedores. Provoca, ainda, a contaminação de águas subterrâneas pela penetração no solo de metais de alta toxidade e o desperdício de materiais recicláveis, com consequente prejuízo aos municípios e à saúde pública (BLUMENSCHEIN, 2007).

Uma das políticas nacionais desenvolvidas para o gerenciamento de resíduos sólidos foi a publicação da Resolução $n^{\circ} 307$ do Conselho Nacional do Meio Ambiente (CONAMA, 2002), na qual os resíduos gerados pela construção civil são classificados em quatro diferentes classes:

- Classe A - resíduos reutilizáveis ou recicláveis como agregados (por exemplo, tijolo, concreto, etc.);

- Classe B - resíduos reutilizáveis ou recicláveis para outras indústrias (por exemplo, plástico, papel, gesso, etc.);

- Classe C - resíduos para os quais não foram desenvolvidas tecnologias viáveis que permitam sua reciclagem;

- Classe D - resíduos perigosos (por exemplo, tintas, solventes, etc.), ou contaminados (por exemplo, provenientes de clínicas radiológicas, instalações industriais e outros).
Em 2012, instituiu-se, por meio da Resolução no 448 do CONAMA, a responsabilidade ambiental que os geradores de resíduos terão de arcar, tratando da redução na geração e ampliação da reutilização, reciclagem e tratamento e disposição dos rejeitos finais (CONAMA, 2012).

No Brasil e no mundo, de uma forma geral, tem crescido o número de pesquisas com finalidade de propor soluções para o problema de geração de resíduos na construção (BLUMENSCHEIN, 2004). A tendência atual é que o impacto produzido pelas edificações sobre o meio ambiente seja o menor possível e que haja uma maior preocupação com a sustentabilidade do desenvolvimento. Essa sustentabilidade sugere uma escolha mais adequada do tipo de material que será utilizado na construção, gerando reduções em custos e desperdícios em consonância com questões sociais e ambientais (REZENDE et al., 2012).

Nesse sentido, muitas empresas optam pela utilização de peças pré-moldadas por atender uma das necessidades prioritárias da construção civil, que é o tempo, e, ainda, reduzir a geração de resíduos, pois o emprego de peças pré-fabricadas para execução da estrutura elimina a necessidade de fôrmas e escoramento, entre outros materiais, que geram resíduos. Entretanto, nesse sistema construtivo também se deve considerar a necessidade de cumprimento da legislação ambiental referente ao gerenciamento dos resíduos, em especial nas indústrias de estruturas pré-moldadas. Esses resíduos são nobres e possuem um grande potencial de serem reutilizados nas próprias indústrias, desde que de maneira correta.

A reciclagem dos Resíduos da Construção Civil (RCC) é de fundamental importância ambiental, no sentido de que os referidos resíduos retornem como substituição a novas matériasprimas que seriam extraídas do meio ambiente. Entretanto, ainda é vista de maneira negativa pela construção civil as iniciativas que se referem à pesquisa de novas tecnologias que aparentemente não se traduzem em grandes vantagens 
financeiras, não havendo grande mobilização do setor.

Os resíduos que se enquadram na classe A e B, de acordo com a classificação do CONAMA 307 , são resíduos com possibilidades de serem absorvidos por processos de reciclagem. Os resíduos classe B, ou seja, papel, papelão, metal, plástico, gesso, entre outros, podem ser absorvidos por processos de reciclagem por indústrias externas ao setor da construção civil. Já os resíduos classe $A$ (que se apresentam em maior quantidade) podem ser absorvidos pela cadeia principal da construção civil. Estes, uma vez reciclados, podem ser utilizados, por exemplo, na execução de bases e sub-bases de pavimentação, na confecção de blocos para vedação, entre outros (BLUMENSCHEIN, 2007).

Tanto no Brasil como em outros países, a maior parte do mercado de agregados é voltada para o emprego em concretos e em argamassas. No Brasil, se todo o RCD fosse destinado à produção de elementos à base de cimento, ele ocuparia apenas cerca de $20 \%$ do mercado de agregados naturais. Já é sabido que o emprego dos agregados de RCD reciclados em concreto é viável, no entanto, as normas para uso de agregados de RCD reciclados em concretos não são facilmente aplicáveis nas usinas de reciclagem devido a: a) heterogeneidade da composição do RCD e variabilidade das propriedades dos agregados reciclados; b) falta de controle das operações de processamento; c) quantificação de fases no material por análise visual, que é subjetiva, não garantindo homogeneidade do produto final e não apresentando uma relação clara com o desempenho dos concretos (ANGULO, 2005). Por essa razão, as normas nacionais permitem o uso dos agregados reciclados apenas em concretos de baixa resistência e responsabilidade.

Sendo assim, o objetivo desta pesquisa foi verificar a influência da substituição dos agregados graúdos naturais por agregados graúdos reciclados oriundos de resíduos de construção e demolição sobre as propriedades mecânicas do concreto. Mais especificamente, procurou-se determinar o teor ideal de substituição do agregado natural pelo agregado reciclado de forma a não haver redução significativa da resistência do concreto. Além disso, buscou-se verificar a influência do agregado reciclado no módulo de elasticidade do concreto. De forma secundária, procurou-se analisar a influência do agregado reciclado na trabalhabilidade do concreto no estado fresco. Também foi proposto um tratamento mecânico do agregado reciclado de modo a obter um agregado graúdo de melhor qualidade. Para isso, foi proposto o tratamento do agregado reciclado no equipamento de abrasão de "Los Angeles" de modo a realizar a limpeza superficial dos agregados graúdos naturais que compõem o agregado reciclado. Buscou-se, assim, minimizar a influência negativa do agregado reciclado nas propriedades do concreto.

\subsection{CARACTERIZAÇÃO DE AGREGADOS RECICLADOS}

São necessários procedimentos sistematizados para a produção de agregados reciclados e sua utilização na construção civil. Existem características físicas e químicas comuns aos diferentes tipos de agregados reciclados aplicáveis em argamassas e concreto e a partir da identificação de algumas dessas características, e da fixação de valores e limites para cada uma delas, é possível garantir a qualidade nas aplicações (LIMA, 1999).

Para a caracterização dos agregados reciclados, alguns métodos podem ser utilizados, tais como a análise granulométrica, a análise química, a análise mineralógica, a análise termogravimétrica, a separação por densidade empregando líquidos densos e a determinação da massa específica aparente e da absorção de água dos agregados (ANGULO, 2005). Dentre essas propriedades, as que mais apresentam influência na resistência do concreto são a massa específica e a absorção de água.

Alguns resultados encontrados na literatura mostram que a separação por densidade é uma técnica eficiente para separar os agregados reciclados em subgrupos de diferentes porosidades, gerando concretos com 
comportamento mecânico e absorção de água similar. Esses resultados indicam uma densidade mínima em torno de 2,2 a $2,3 \mathrm{~kg} / \mathrm{dm}^{3}$. A partir desse limite, os agregados reciclados possuem teores elevados de rochas e teores baixos de cerâmica vermelha, resultando em concretos com comportamento mecânico semelhante ao dos concretos com agregados naturais (ANGULO, 2005).

Outra forma de obter agregados reciclados com valores de densidade acima de 2,3 $\mathrm{kg} / \mathrm{dm}^{3}$ foi proposto por Pepe et al. (2014). Nesse trabalho, os autores utilizaram um pequeno moinho de tambor rotativo, com velocidade de 60 rotações por minuto, no qual os agregados reciclados foram adicionados por tempos que variaram de 10 a 15 minutos. Nesse processo, a argamassa aderida aos agregados graúdos naturais presentes nos agregados reciclados era retirada pelo choque entre os agregados. Com isso, ao final eram obtidos agregados graúdos com morfologia e absorção próximas aos do agregado natural. Com essa metodologia, os autores realizaram a substituição total dos agregados naturais pelos agregados reciclados tratados e obtiveram concretos com resistência à compressão próxima de $30 \mathrm{MPa}$ e com menos de $10 \%$ de redução de resistência quando comparado ao concreto com agregados naturais.

\subsection{PESQUISAS SOBRE CONCRETO ESTRUTURAL COM AGREGADO RECICLADO}

Segundo Lima (1999), as características dos concretos com agregados reciclados variam mais que as de concretos convencionais. Apesar disto, podem-se obter concretos com agregados reciclados adequados a diversos serviços de construção, inclusive alguns de responsabilidade estrutural. Isso é possível desde que sejam tomados cuidados na produção do agregado e do novo concreto, tais como, a escolha do resíduo, a classificação e separação de contaminantes, o controle de qualidade, a adoção de procedimentos corretos de aplicação, a análise das condições de exposição, dentre outros.

Tenório (2007) avaliou algumas das propriedades mecânicas e de durabilidade do concreto produzido com agregados miúdos e graúdos reciclados de $\mathrm{RCD}$ para analisar a possibilidade de uso desses agregados em estruturas. Para isso, o autor concentrou-se no nível de porosidade e resistência do agregado graúdo reciclado, tomando como um dos parâmetros do estudo a massa específica do agregado reciclado. Foram produzidos quinze traços de concreto, variando a relação água/cimento $(0,67-0,50-0,40)$ e a massa específica do agregado graúdo (2,08 e $\quad 2,27$ $\mathrm{kg} / \mathrm{dm}^{3}$ ). Ambos os agregados reciclados possuíam menor massa específica e maior absorção de água que o agregado natural, confirmando a presença de materiais mais porosos e menos densos nas suas composições. Em termos de propriedades mecânicas, os concretos reciclados apresentaram resistências à compressão ligeiramente inferiores às dos concretos convencionais. Pelos resultados encontrados, o autor afirma que é possível o uso do agregado reciclado em aplicações estruturais, desde que observadas suas particularidades: sua menor resistência, maior deformabilidade e maior permeabilidade, as quais podem vir a serem fatores limitantes em alguns casos.

Com o intuito de ampliar os conhecimentos já existentes referentes aos materiais de construção reciclados, Carrijo (2005) analisou a influência da massa específica dos agregados reciclados no comportamento mecânico e nas propriedades físicas do concreto estrutural. Por meio da separação em diferentes faixas de densidade, o autor obteve agregados reciclados de comportamento mais homogêneo para poder possibilitar a utilização dos agregados em situações de maior controle. Para o estudo, a densidade foi considerada como o principal fator de diferenciação entre os agregados graúdos reciclados de $R C D$.

A separação por faixas de densidade mostrou ser um critério confiável de classificação e caracterização dos agregados para a fabricação de concretos. O emprego de agregados reciclados na faixa de densidade de 2,2 a $2,5 \mathrm{~kg} / \mathrm{dm}^{3}$, em 
comparação ao concreto utilizando agregados naturais, não resultou em aumento significativo do consumo de cimento em concretos de resistências semelhantes. Já nos concretos com agregados reciclados com menores densidades, as relações consumo/resistência foram altas, tornando estes concretos economicamente menos vantajosos que os concretos tradicionais (CARRIJO, 2005).

Yang et al. (2008) realizaram experimentos em nove traços de concreto para avaliar a influência da substituição dos agregados naturais por agregados reciclados de RCD. Estes foram classificados em três diferentes tipos de acordo com sua massa específica e absorção de água: 1) agregado graúdo reciclado com massa específica de $2,53 \mathrm{~kg} / \mathrm{dm}^{3}$ e absorção de água de $1,9 \%$; 2) agregado graúdo reciclado com massa específica de $2,40 \mathrm{~kg} / \mathrm{dm}^{3}$ e absorção de água de 3,2\%; 3) agregado miúdo reciclado com massa específica de $2,36 \mathrm{~kg} / \mathrm{dm}^{3}$ e absorção de água de $5,4 \%$. Os níveis de substituição de ambos os agregados reciclados, graúdo e miúdo, foram 30\%, $50 \%$ e $100 \%$. Para o concreto fresco foram determinados o abatimento e a exsudação.

Yang et al. (2008) chegaram a várias conclusões, sendo as mais importantes:

- O abatimento do concreto com agregados reciclados foi ligeiramente afetado pela maior absorção de água dos agregados, sendo tanto menor quanto maior a absorção do agregado;

- A quantidade total de água e a taxa de exsudação do concreto fresco decresceram com o aumento da absorção de água dos agregados reciclados;

- A resistência à compressão do concreto com agregados graúdos reciclados com baixa absorção foi similar ao do concreto de referência com agregados naturais, apresentando redução menor que $10 \%$. No entanto, a resistência à compressão do concreto com agregados miúdos e graúdos de alta absorção, foi equivalente a $60 \%$ e $80 \%$ da resistência do concreto de referência com agregados naturais nas idades iniciais de 1 a 3 dias. Já aos 28 dias, o concreto com 100\% de agregados reciclados apresentou uma redução de até $32 \%$ na resistência quando comparado ao concreto de referência;

- A resistência à tração e o módulo de elasticidade do concreto com agregados reciclados também diminuíram com o aumento da absorção de água dos agregados.

Lin et al. (2004) realizaram um amplo estudo experimental para propor metodologias otimizadas de cálculo de traços de concreto com agregados graúdos e miúdos reciclados. Os autores concluíram que o melhor desempenho para o concreto, do ponto de vista de trabalhabilidade e resistência mecânica, é alcançado quando $42 \%$ do agregado graúdo natural é substituído por agregados reciclados e se utiliza uma relação água/cimento igual a 0,5. Já Cabral et al. (2010) mostraram que as propriedades mecânicas do concreto são mais afetadas pela presença do agregado graúdo reciclado que do agregado miúdo reciclado. Neste caso, os autores observaram redução de $19 \%$ e $21 \%$ na resistência à compressão e no módulo de elasticidade, respectivamente, quando foram utilizados $100 \%$ de agregados graúdos reciclados oriundos de resíduos de concreto. Também, Cabral et al. (2012) mostraram uma redução de até $27 \%$ na resistência à compressão e de até $26 \%$ no módulo de elasticidade do concreto quando $100 \%$ do agregado graúdo natural foi substituído pelo agregado graúdo reciclado, independente da cidade de origem do agregado reciclado utilizado.

Com relação à aplicação estrutural de concretos com agregados reciclados, Kang et al. (2014) testaram 28 vigas de concreto armado à flexão, com resistência à compressão do concreto variando de $27 \mathrm{MPa}$ a $54 \mathrm{MPa}$. A taxa de substituição dos agregados naturais pelos agregados reciclados variou de $15 \%$ a $50 \%$, sendo que estes possuíam uma massa específica semelhante a do agregado natural. Os autores observaram uma redução de até $25 \%$ na resistência à compressão do concreto e de $19 \%$ na resistência à tração indireta com a substituição de $30 \%$ ou $50 \%$ dos agregados naturais pelos 
agregados reciclados. Além disso, eles observaram uma redução da ductilidade das vigas com agregados reciclados, porém não observaram redução do momento resistente da viga. Com isso, os autores sugeriram limitar em 30\% a taxa de substituição dos agregados naturais pelos agregados reciclados.

Outros trabalhos recentes foram desenvolvidos buscando analisar a influência dos agregados reciclados nas propriedades mecânicas do concreto e sua aplicação em elementos com função estrutural (AREZOUMANDI et al., 2015; PACHECO et al., 2015; RAHAL e AL-KHALEEFI, 2015). De forma geral, esses trabalhos mostram que é possível a substituição de 50\% a $100 \%$ dos agregados naturais pelos agregados reciclados sem prejuízo das propriedades mecânicas do concreto. Para isso, o fator mais importante é o emprego de agregados reciclados de boa qualidade e oriundos de resíduos cinzas.

\section{PROGRAMA EXPERIMENTAL}

Tendo em vista os diferentes resultados encontrados na literatura, foi desenvolvido um programa experimental de modo a determinar a influência dos agregados reciclados nas propriedades mecânica do concreto. Neste item são apresentadas as propriedades dos materiais empregados na pesquisa e os métodos utilizados para a caracterização do concreto. A principal variável da pesquisa foi o teor de substituição do agregado graúdo natural pelo agregado reciclado, tendo sido adotados os teores de 19\%, 43\%, 75\% e $100 \%$ de substituição. Além disso, é analisado um método alternativo para tratamento do agregado reciclado, buscando obter um agregado graúdo com maior massa específica. Neste caso, foi adotado apenas o teor de $26 \%$ de substituição do agregado natural pelo agregado reciclado tratado. Foi analisada a influência do teor de substituição dos agregados nas propriedades do concreto no estado fresco (massa específica e teor de ar) e no estado endurecido (resistência à compressão, resistência à tração e módulo de elasticidade).

\subsection{MATERIAIS}

Na confecção do concreto foi utilizado um Cimento Portland CP-II Z 32. Os agregados reciclados foram preparados e fornecidos já triturados, a partir de resíduos de construção e demolição que se enquadram na Classe $A$ da resolução no 307 do CONAMA (2002), por uma empresa da região de Goiânia.

A água utilizada na dosagem era limpa e captada da rede pública. Foi utilizado um aditivo superplastificante para melhorar a trabalhabilidade da mistura. Trata-se de uma solução aquosa de policarboxilatos modificados com densidade de $1,09 \pm 0,02 \mathrm{~kg} / \mathrm{L}$ e $\mathrm{pH}$ de $4,5 \pm 1,0$ (SIKA, 2014).

\subsubsection{AGREGADOS RECICLADOS}

Os agregados reciclados fornecidos tinham como origem resíduos de concreto e argamassa de construção e demolição, também denominado resíduo "cinza". Da inspeção visual dos mesmos, foi observada a presença de alguns agregados graúdos envolvidos por restos de concreto, argamassas e um pouco de fino. Da caracterização granulométrica desse agregado, observou-se que a parcela, em massa, que passou pela peneira com abertura de $4,75 \mathrm{~mm}$ foi de apenas 8\%. Dessa forma, visando melhorar a trabalhabilidade do concreto, o agregado reciclado foi previamente peneirado, descartando os finos.

A seleção criteriosa da origem do resíduo de construção pela indústria, aliada a esse procedimento, permitiu um agregado reciclado bruto de boa qualidade. Visualmente, foram observados poucos resíduos de cerâmica (Figura 1). Além disso, a massa específica do agregado reciclado bruto apresentou um valor acima de 2,2 $\mathrm{kg} / \mathrm{dm}^{3}$, valor mínimo recomendado para uso no concreto estrutural e muito próximo da massa específica dos agregados naturais. Por outro lado, o agregado reciclado apresentou uma absorção maior que a do agregado natural, chegando a quase $7 \%$ de absorção. Na Tabela 1 é apresentado o resumo das propriedades físicas dos agregados. A massa específica e o índice de absorção de água 
dos agregados graúdos foram obtidos pela NBR NM 53 (ABNT, 2009) e a massa específica do agregado miúdo foi determinada pela NBR 9776 (ABNT, 1987).

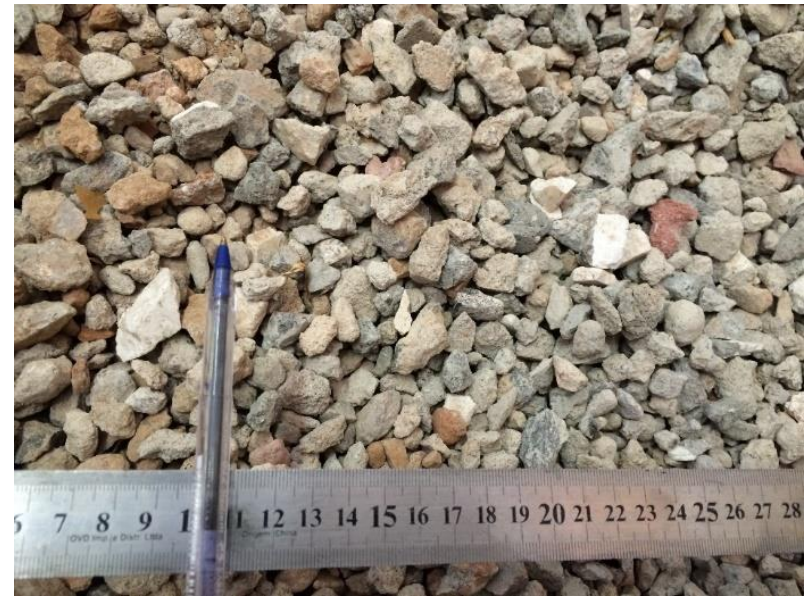

FIGURA 1: Aspecto visual do agregado reciclado bruto.

Nessa pesquisa, o agregado reciclado bruto foi submetido a um tratamento mecânico na tentativa de recuperar os agregados naturais dos resíduos de construção. Para isso, foi empregado o equipamento de abrasão "Los Angeles" (Figura 2), conforme NBR NM 51 (ABNT, 2001), como forma alternativa ao moinho de tombamento para a limpeza dos agregados reciclados utilizado no trabalho de Pepe et al. (2014). Para este estudo, foram colocados na máquina, de cada vez, $5 \mathrm{~kg}$ de agregado reciclado bruto com 11 esferas, sendo o ensaio realizado durante aproximadamente 18 minutos com 500 rotações. Após o ensaio, foi realizada a separação do material graúdo do material fino utilizando uma peneira com malha 2,36 mm.

Ao final desse processo, os agregados obtidos apresentaram uma massa específica praticamente igual à massa específica dos agregados naturais. Além disso, a absorção foi reduzida pela metade, alcançando um valor próximo de $3 \%$, porém ainda acima da absorção do agregado natural. Esse valor foi semelhante ao encontrado por Pepe et al. (2014), porém a massa específica obtida no presente trabalho foi maior, provavelmente pela diferença de composição mineralógica entre os agregados. Isso demonstra a eficiência do equipamento de abrasão de "Los Angeles" como alternativa para a limpeza dos agregados reciclados.

No tratamento realizado, a taxa de recuperação do agregado graúdo foi de $53 \%$, em massa. O restante do material obtido apresentou uma composição granulométrica semelhante à da areia natural, com um pouco mais de finos, talvez podendo ser utilizada como uma areia artificial. Para isso, outros ensaios devem ser realizados para caracterizar as propriedades físicas e químicas desse resíduo fino.

TABELA 1: Propriedades físicas dos agregados.

\begin{tabular}{|c|c|c|c|c|c|}
\hline & $\begin{array}{l}\text { Massa específica } \\
\qquad\left(\mathrm{kg} / \mathrm{dm}^{3}\right)\end{array}$ & $\begin{array}{c}\text { Massa Específica } \\
\text { Aparente } \\
\left(\mathrm{kg} / \mathrm{dm}^{3}\right)\end{array}$ & $\begin{array}{c}\text { Dimensão } \\
\text { Máxima } \\
\text { Característica } \\
(\mathrm{mm})\end{array}$ & $\begin{array}{l}\text { Módulo de } \\
\text { Finura }\end{array}$ & $\begin{array}{c}\text { Absorção de } \\
\text { água (\%) }\end{array}$ \\
\hline Areia Natural & 2,53 & - & 1,18 & 3,93 & - \\
\hline Brita 0 & 2,67 & 2,58 & 12,5 & 3,07 & 1,29 \\
\hline Brita 1 & 2,65 & 2,62 & 19,0 & 4,90 & 0,52 \\
\hline Agregado Reciclado bruto & 2,58 & 2,20 & 19,0 & 4,15 & 6,69 \\
\hline $\begin{array}{c}\text { Agregado Reciclado } \\
\text { Tratado }\end{array}$ & 2,70 & 2,48 & $>12,5$ & 2,53 & 3,31 \\
\hline
\end{tabular}




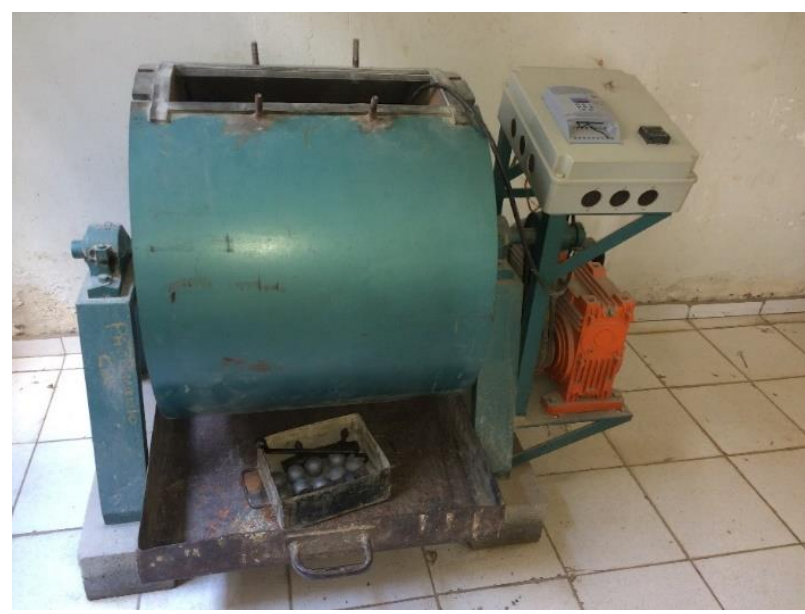

FIGURA 2: Equipamento de abrasão "Los Angeles".

A composição granulométrica dos agregados naturais e dos agregados reciclados foi obtida conforme procedimento descrito na NBR NM 248 (ABNT, 2003). Os resultados obtidos são mostrados na Tabela 2 , da qual se conclui que o agregado reciclado bruto, tal como recebido da indústria, pode ser classificado como Brita 1 (D = $19 \mathrm{~mm}$ ).

$\mathrm{Na}$ Figura 3 são mostradas as curvas granulométricas obtidas para o agregado miúdo, para os agregados graúdos natural (Brita 0 e Brita 1) e para o agregado reciclado. Nessa figura também são mostrados os limites da zona utilizável para produção de concreto, recomendados pela NBR 7211 (ABNT, 2009). Já na Figura 4 é mostrada a curva granulométrica do agregado graúdo reciclado e tratado, bem como a curva granulométrica do fino resultante do tratamento na máquina de abrasão "Los Angeles".

Nota-se que as curvas obtidas para os agregados graúdos ficaram fora do intervalo padrão e que apenas a areia natural atendeu aos limites especificados da zona utilizável. Portanto, foi realizada a composição teórica dos agregados graúdos. Para isso, foi empregado um método baseado nos mínimos quadrados, isto é, a composição granulométrica resultante da mistura apresentará variações com relação aos valores médios da faixa especificada, cuja soma dos quadrados dessas variações deve ser mínima. Foi, assim, obtida a curva granulométrica compensada para os agregados naturais e que está mostrada na Figura 5 (Traço C-0). Essa curva resulta da mistura de $67 \%$ de Brita 1 e $33 \%$ de Brita 0 e possui módulo de finura igual a 4,29.

TABELA 2: Composição granulométrica dos agregados.

\begin{tabular}{|c|c|c|c|c|c|c|}
\hline \multirow[b]{2}{*}{ Peneira } & \multicolumn{6}{|c|}{$\%$ massa retida acumulada } \\
\hline & $\begin{array}{l}\text { Areia } \\
\text { Natural }\end{array}$ & Brita 0 & Brita 1 & $\begin{array}{c}\text { Agregado reciclado } \\
\text { bruto }\end{array}$ & $\begin{array}{c}\text { Agregado } \\
\text { reciclado tratado }\end{array}$ & $\begin{array}{l}\text { Resíduo Fino do ag. } \\
\text { reciclado tratado }\end{array}$ \\
\hline 31,5 & - & $0 \%$ & $0 \%$ & $0 \%$ & $0 \%$ & - \\
\hline 25 & - & $0 \%$ & $0 \%$ & $0 \%$ & $0 \%$ & - \\
\hline 19 & - & $0 \%$ & $1 \%$ & $4 \%$ & $0 \%$ & - \\
\hline 12,5 & - & $1 \%$ & $91 \%$ & $46 \%$ & $13 \%$ & - \\
\hline 9,5 & $0 \%$ & $38 \%$ & $98 \%$ & $71 \%$ & $30 \%$ & $0 \%$ \\
\hline 6,3 & $0 \%$ & $74 \%$ & $99 \%$ & $89 \%$ & $41 \%$ & $0 \%$ \\
\hline 4,75 & $0 \%$ & $88 \%$ & $100 \%$ & $92 \%$ & $59 \%$ & $0 \%$ \\
\hline 2,36 & $0 \%$ & $97 \%$ & $100 \%$ & $96 \%$ & $94 \%$ & $0 \%$ \\
\hline 1,18 & $4 \%$ & - & - & - & - & $10 \%$ \\
\hline 0,6 & $20 \%$ & - & - & - & - & $32 \%$ \\
\hline 0,3 & $50 \%$ & - & - & - & - & $49 \%$ \\
\hline 0,15 & $91 \%$ & - & - & - & - & $67 \%$ \\
\hline
\end{tabular}




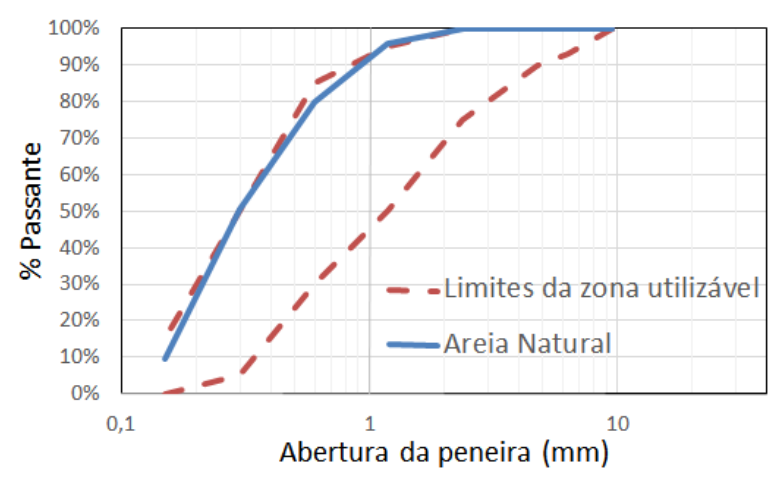

[a]

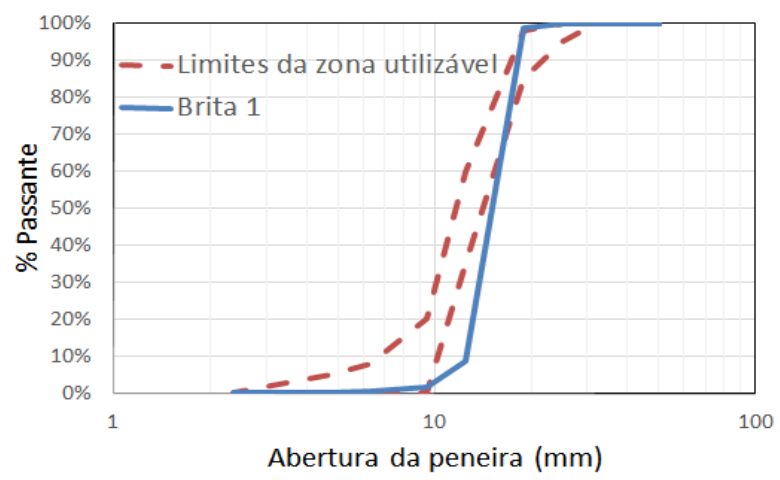

[c]

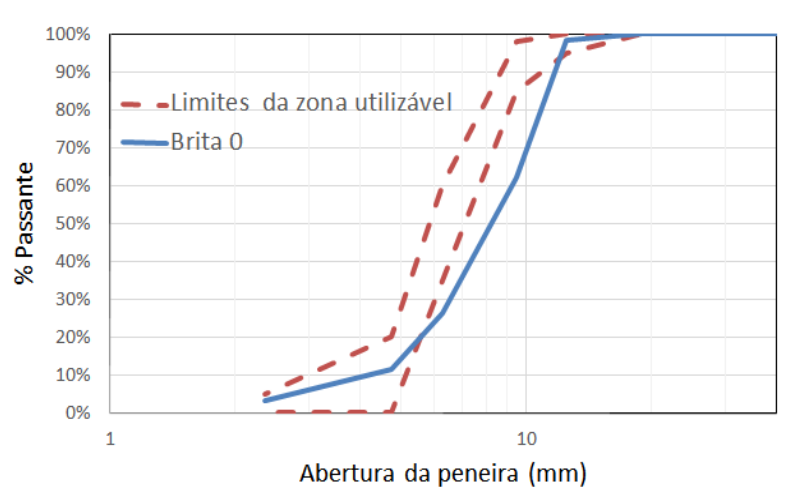

[b]

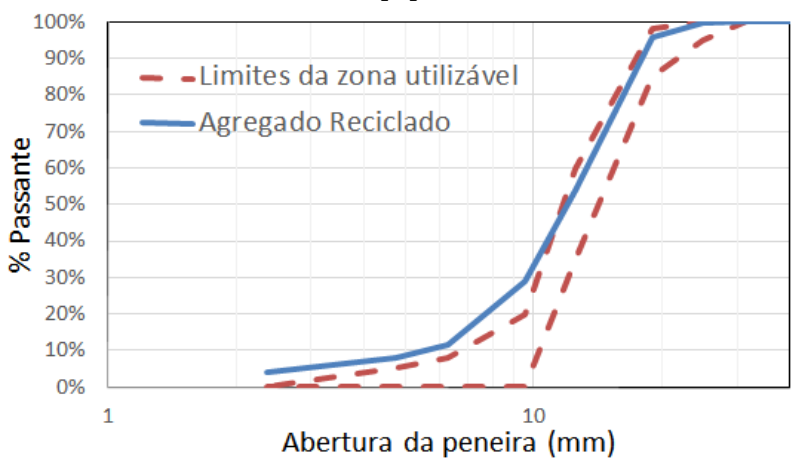

[d]

FIGURA 3: Curva granulométrica dos agregados: [a] Areia natural; [b] Agregado natural - Brita 0; [c] Agregado Natural - Brita 1; [d] Agregado Reciclado bruto.

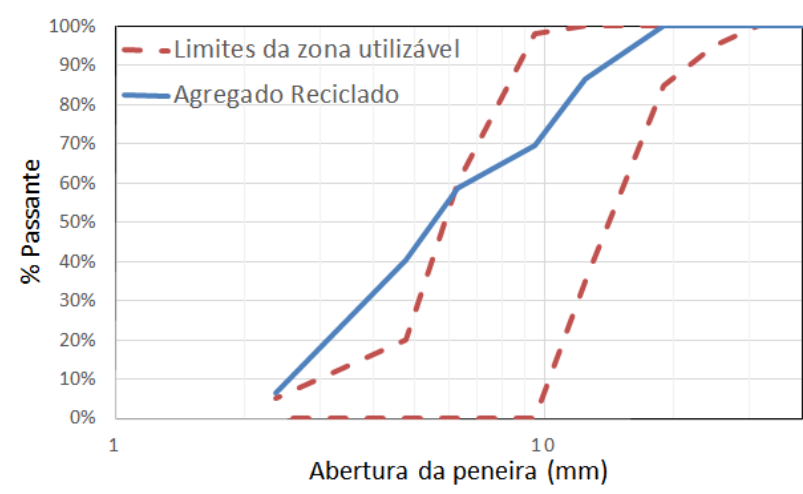

[a]

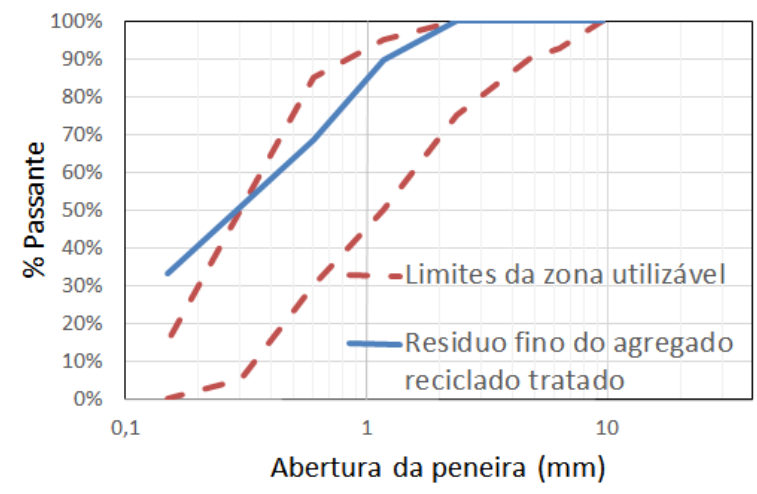

[b]

FIGURA 4: Curva granulométrica do agregado reciclado tratado: [a] Parcela retida na peneira de 2,36 mm; [b] Resíduo passante na peneira de $2,36 \mathrm{~mm}$.

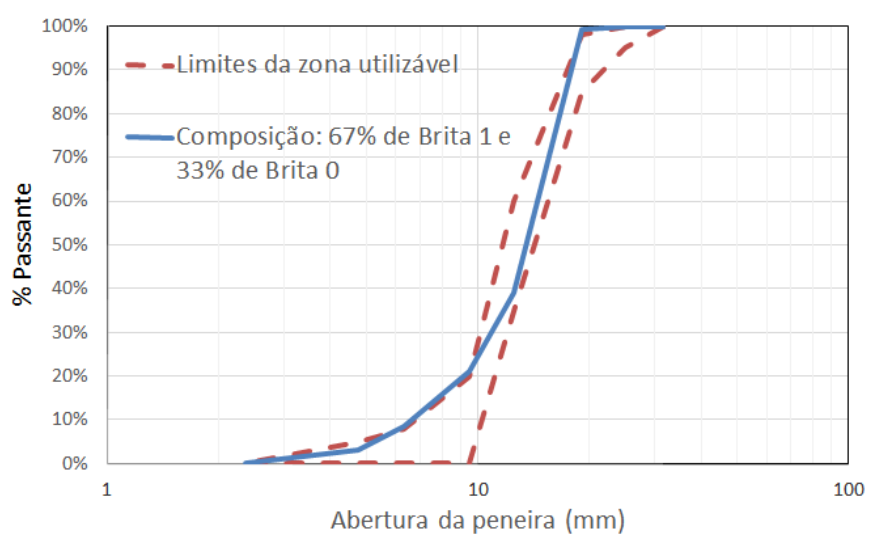

FIGURA 5: Composição para o traço de referência com 0\% de substituição (Traço C-0). 


\subsubsection{TRAÇOS DE CONCRETO}

$\mathrm{O}$ traço de referência com os agregados naturais (Traço C-0) foi calculado a partir da metodologia clássica do $\mathrm{ACl} 211.1$ (Standard Practice for Selecting Proportions for Normal, Heavy Weght, and Mass Concrete) e relatada em Metha e Monteiro (2008). O método utilizado é composto por nove passos:

I. Escolha do abatimento, entre $80 \mathrm{~mm}$ e 100 $\mathrm{mm}$;

II. Definição da dimensão máxima do agregado, que neste caso era igual a $19 \mathrm{~mm}$;

III. Escolha do teor de água, igual a $216 \mathrm{~kg} / \mathrm{m}^{3}$;

IV. Definição da relação água/cimento, escolhida igual a 0,45 para obter uma resistência à compressão média aos 28 dias de $40 \mathrm{MPa}$;

V. Cálculo do consumo de cimento;

VI. Escolha do teor de agregado graúdo compactado seco, adotado igual a $60 \%$;

VII. Cálculo da quantidade de areia a partir da massa específica do concreto, adotada igual a $2345 \mathrm{~kg} / \mathrm{m}^{3}$. De posse dessas informações, chega-se ao traço unitário em massa 1: 1,44: 2,0: 0,45 (cimento : areia : agregado graúdo : água) , que foi mantido constante no estudo;

VIII. Ajuste da quantidade de água em função da umidade dos agregados no laboratório. Esse ajuste se faz necessário porque o agregado miúdo foi utilizado com sua umidade natural. Dessa forma, a quantidade de água da mistura foi reduzida em função da quantidade de água presente no agregado miúdo por meio de secagem em estufa por 24 horas antes do início da concretagem. Os agregados graúdos (naturais e reciclados) foram utilizados secos ao ambiente. A caracterização inicial dos mesmos mostrou que o teor de umidade nos mesmos nessa condição era muito baixo e podia ser desconsiderado;

IX. Ajuste do teor do aditivo superplastificante de modo a obter o abatimento dentro de uma faixa especificada, aqui adotada como sendo $100 \pm 20 \mathrm{~mm}$.
Depois de realizado o ajuste experimental do traço, a massa específica do concreto no estado fresco foi determinada. De posse dessa informação, foi realizado o ajuste final das quantidades de materiais de modo a obter o traço por metro cúbico de concreto. O traço final de referência, em massa, é mostrado na Tabela 3. Esse mesmo ajuste foi realizado para os traços com os agregados reciclados, o que resultou na variação do consumo de cimento em função do teor de substituição adotado.

Definido o traço de referência, foram calculados quatro traços com parte da Brita 1 natural substituída pelo agregado reciclado bruto. Foram adotados os seguintes níveis de substituição, em massa: 25\%, 50\%, $75 \%$ e $100 \%$. Porém, a composição granulométrica do agregado reciclado bruto era diferente da Brita 1 natural. Dessa forma, optou-se por fazer a composição teórica da mistura agregado reciclado bruto e Brita $1 \mathrm{com}$ a Brita 0 de modo semelhante ao que havia sido feito para os agregados naturais. Com isso, buscava-se manter a mesma trabalhabilidade do traço de referência nos traços com agregados reciclados. Desse cálculo, foram obtidas as porcentagens finais de substituição dos agregados naturais (Brita 1 mais Brita 0) pelo agregado reciclado e que estão mostradas na Tabela 3.

$\mathrm{Na}$ Figura 6 são mostradas as curvas granulométricas da composição entre os agregados naturais e o agregado reciclado bruto.

A Tabela 3 mostra um último traço com substituição parcial dos agregados naturais pelo agregado reciclado (Traço CT-26). Este traço se difere dos demais pelo uso do agregado reciclado tratado por meio da máquina de abrasão "Los Angeles". Nesse caso, esse agregado foi composto apenas com a Brita 1 natural. Isso resultou na composição de $74 \%$ de Brita 1 natural e $26 \%$ de agregado reciclado tratado e na curva granulométrica mostrada na Figura 7. 
TABELA 3: Traço para confecção de um metro cúbico de concreto.

\begin{tabular}{|c|c|c|c|c|c|c|c|c|}
\hline Traço & $\begin{array}{l}\text { Cimento } \\
\left(\mathrm{kg} / \mathrm{m}^{3}\right)\end{array}$ & $\begin{array}{c}\text { Areia } \\
\text { Natural } \\
\left(\mathrm{kg} / \mathrm{m}^{3}\right)\end{array}$ & $\begin{array}{c}\text { Brita } 0 \\
\left(\mathrm{~kg} / \mathrm{m}^{3}\right)\end{array}$ & $\begin{array}{c}\text { Brita } 1 \\
\left(\mathrm{Kg} / \mathrm{m}^{3}\right)\end{array}$ & $\begin{array}{c}\text { Água } \\
\left(\mathrm{kg} / \mathrm{m}^{3}\right)\end{array}$ & $\begin{array}{c}\text { Agregado } \\
\text { Reciclado } \\
\left(\mathrm{kg} / \mathrm{m}^{3}\right)\end{array}$ & $\begin{array}{l}\text { Aditivo } \\
\left(\mathrm{kg} / \mathrm{m}^{3}\right)\end{array}$ & $\begin{array}{c}\text { Substituição } \\
(\%)\end{array}$ \\
\hline $\mathrm{C}-0$ & 480,3 & 689,4 & 317,2 & 643,4 & 216,1 & - & 1,68 & 0 \\
\hline C-19 & 474,5 & 681,1 & 237,2 & 533,8 & 213,5 & 177,9 & 2,85 & 19 \\
\hline$C-43$ & 471,7 & 677,1 & 131,7 & 405,9 & 212,3 & 405,9 & 3,54 & 43 \\
\hline$C-75$ & 461,9 & 663,0 & - & 230,9 & 207,8 & 692,8 & 3,46 & 75 \\
\hline$C-100$ & 468,6 & 672,6 & - & - & 210,9 & 937,2 & 5,62 & 100 \\
\hline CT-26 & 476,5 & 684,0 & - & 704,9 & 214,4 & 248,2 & 1,91 & 26 \\
\hline
\end{tabular}

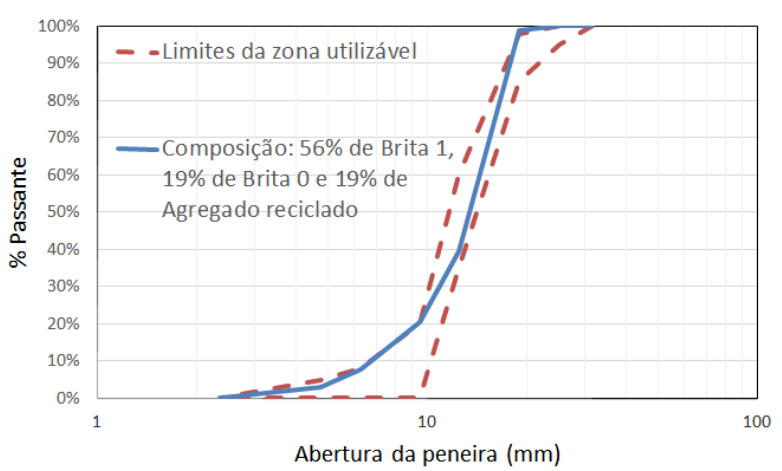

[a]

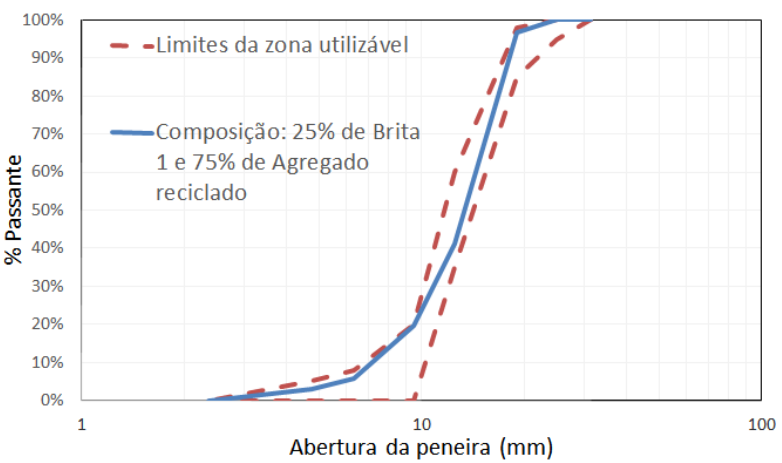

[c]

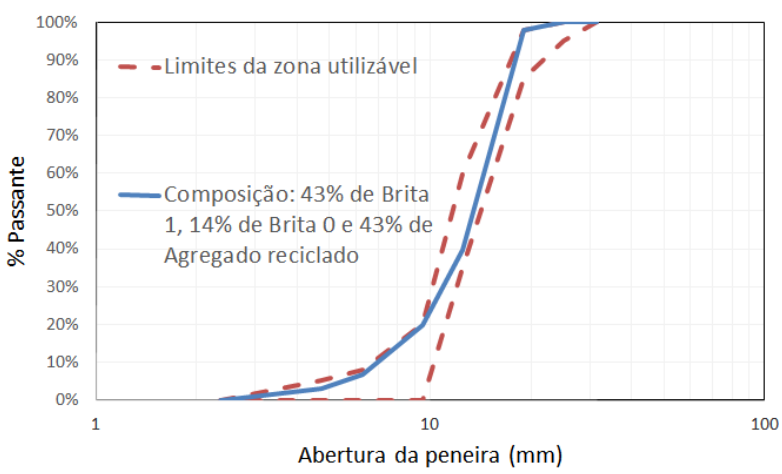

[b]

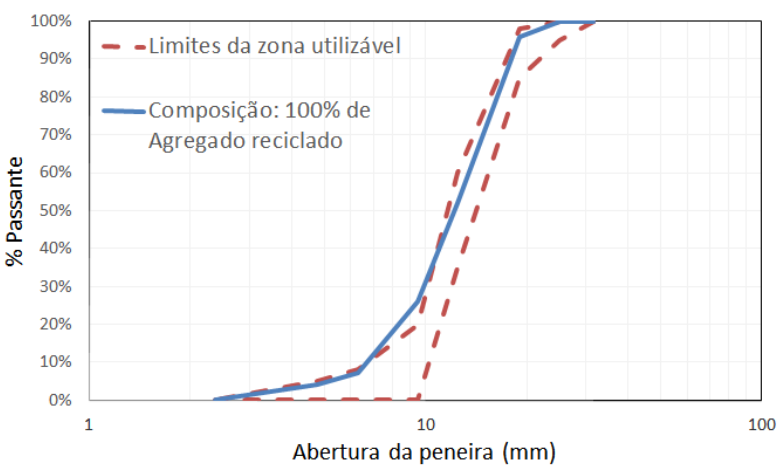

[d]

FIGURA 6: Curva granulométrica da composição dos agregados graúdos: [a] Traço C-19; [b] Traço C-43; [c] Traço C-75; [d] Traço C-100.

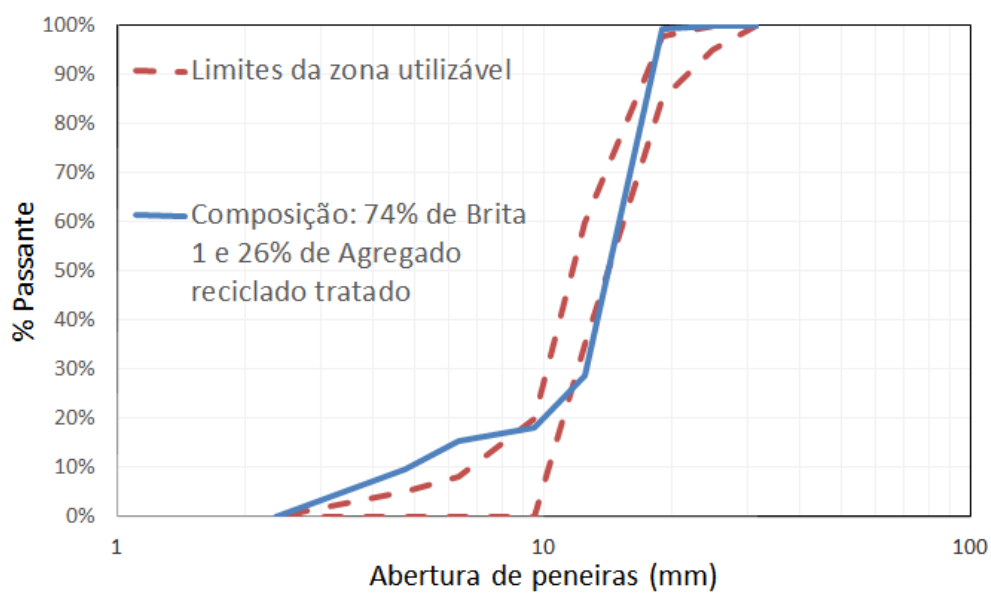

FIGURA 7: Curva granulométrica para o traço com agregado reciclado tratado - $26 \%$ de substituição (Traço CT-26). 


\subsection{MÉTODOS}

Antes de cada mistura, foi feita a imprimação da betoneira, simulando uma concretagem de $0,03 \mathrm{~m}^{3}$. A sequência de introdução dos materiais na betoneira foi:

I. Colocação do agregado graúdo e miúdo na betoneira com aproximadamente $50 \%$ da água de amassamento, misturando por um período de 1 minuto;

II. Adição do cimento e o restante da água e misturando por mais 1 minuto;

III. Adição do aditivo e misturando por mais 3 minutos;

IV. A mistura permanece em descanso por três minutos. Findo este prazo, procedeu-se à mistura por mais três minutos.

A moldagem dos corpos de prova para este estudo foi realizada seguindo a norma ABNT NBR 5738 (ABNT, 2003). Os corpos de prova foram desmoldados com 24 horas, aproximadamente, e mantidos sob cura em uma câmara úmida com temperatura de $20 \circ \mathrm{C} \pm 2 \circ \mathrm{C}$ e umidade acima de 99\%. Eles foram mantidos nessa condição até o momento do ensaio, quando foram retirados e secados superficialmente.

O concreto foi caracterizado em seu estado fresco e no estado endurecido. No estado fresco foram determinadas as seguintes propriedades: abatimento do tronco de cone, conforme a NBR NM 67 (ABNT, 1998); massa específica e teor de ar, conforme a NBR NM 47 (ABNT, 2002). No estado endurecido foram determinadas as seguintes propriedades: resistência à compressão aos 7 e 28 dias, conforme a NBR 5739 (ABNT, 2007); resistência à tração por compressão diametral aos 28 dias, conforme a NBR 7222 (ABNT, 2011); módulo de elasticidade estático aos 28 dias, conforme a NBR 8522 (ABNT, 2008).

Para determinação da resistência à compressão, foram ensaiados, para cada traço, seis corpos de prova cilíndricos de $10 \times 20 \mathrm{~cm}$, sendo três corpos de prova aos 7 dias e três corpos de prova aos 28 dias. Para regularização das superfícies dos corpos de prova e distribuição da carga foram utilizados dois pratos metálicos nas suas extremidades, com uma placa de neoprene intercalada entre os pratos e o corpo de prova, conforme recomendação da ASTM C1231 (ASTM, 2014). Para os ensaios de resistência à tração por compressão diametral e módulo de elasticidade estático foram utilizados, para cada traço, três corpos de prova cilíndricos de $15 \times 30 \mathrm{~cm}$ (Figura 8).

Os resultados da caracterização mecânica do concreto foram analisados estatisticamente por meio do teste de comparações múltiplas de médias, utilizando o teste de Tukey com intervalo de confiança de $95 \%$.

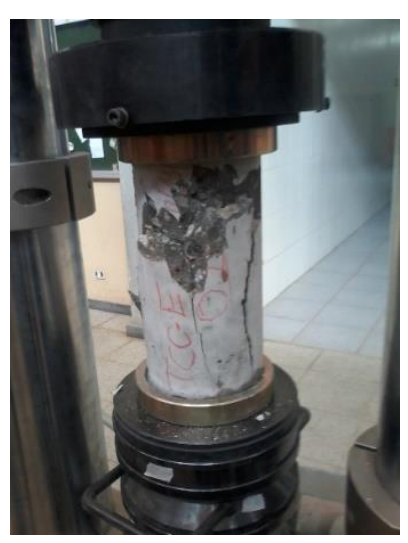

[a]

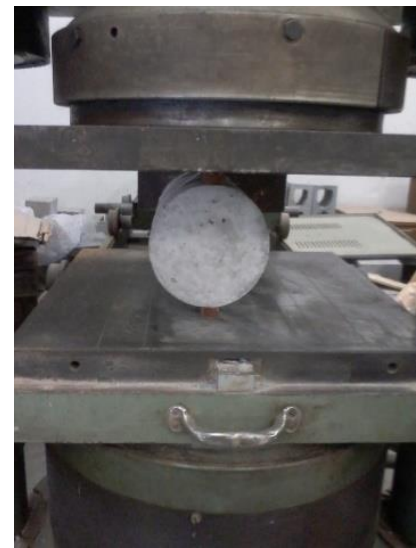

[b]

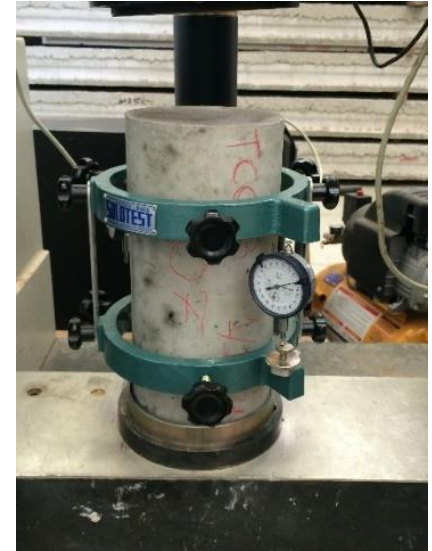

[c]

FIGURA 8: Ensaios de caracterização do concreto no estado endurecido: [a] resistência à compressão; [b] resistência à tração por compressão diametral; [c] módulo de elasticidade estático. 


\section{RESULTADOS E DISCUSSÕES}

\subsection{PROPRIEDADES DO CONCRETO NO ESTADO FRESCO}

Em todas as dosagens, foi determinada a massa específica do concreto no estado fresco e o teor de ar da mistura, além de ser analisada a trabalhabilidade pelo abatimento do tronco de cone. Os resultados são mostrados na Tabela 4. Observa-se que com exceção dos traços C-75 e C100 , em todos os demais o abatimento esteve dentro do limite estabelecido de $100 \pm 20 \mathrm{~mm}$.
Isso foi conseguido graças ao aumento do volume de aditivo superplastificante adicionado à mistura devido ao aumento do teor de substituição do agregado natural pelo agregado reciclado. No traço de referência, o volume de aditivo, em relação à massa de cimento, foi de $0,35 \%$, enquanto no traço C-100, com $100 \%$ de substituição, esse volume chegou a 1,2\% (Figura 9). Apesar do aumento do consumo de aditivo, em nenhum dos traços estudados foi observada exsudação do concreto.

\section{TABELA 4: Propriedades do concreto no estado fresco.}

\begin{tabular}{ccccc} 
Traço & Substituição (\%) & Abatimento $(\mathbf{m m})$ & $\begin{array}{c}\text { Massa Específica do } \\
\text { Concreto }\left(\mathbf{k g} / \mathbf{d m}^{\mathbf{3}}\right)\end{array}$ & Teor de ar (\%) \\
\hline C-0 & 0 & 100 & 2,35 & 2,0 \\
C-19 & 19 & 85 & 2,32 & 2,2 \\
C-43 & 43 & 95 & 2,31 & 2,4 \\
C-75 & 75 & 215 & 2,26 & 2,8 \\
C-100 & 100 & 70 & 2,30 & 2,9 \\
CT-26 & 26 & 85 & 2,33 & 2,2 \\
\hline
\end{tabular}

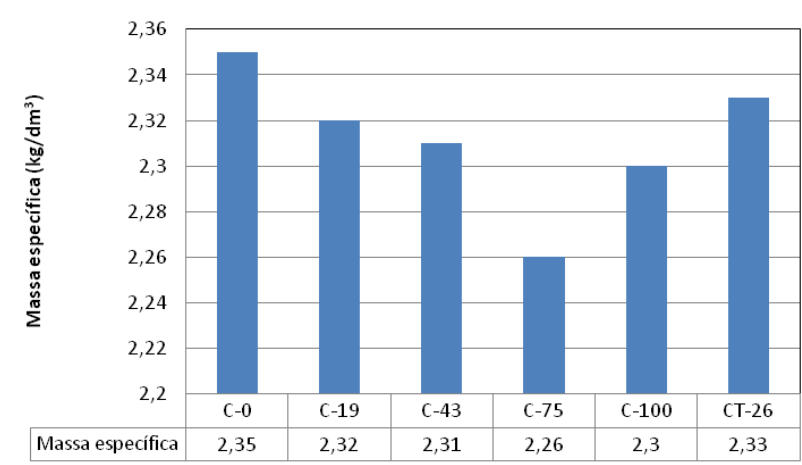

[a]

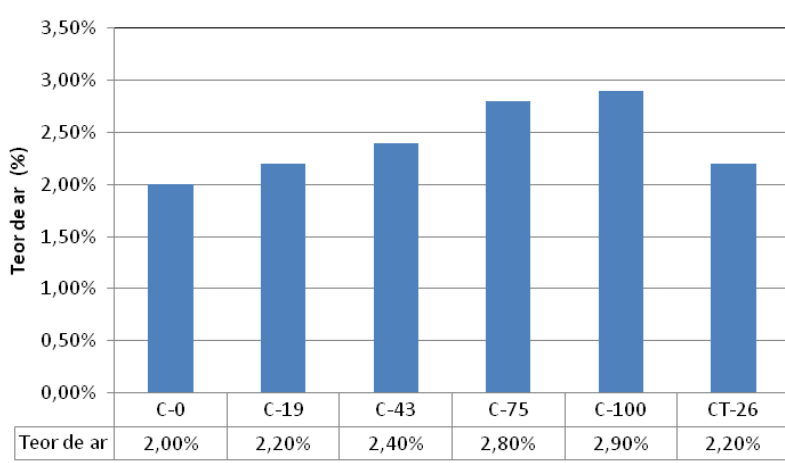

[b]

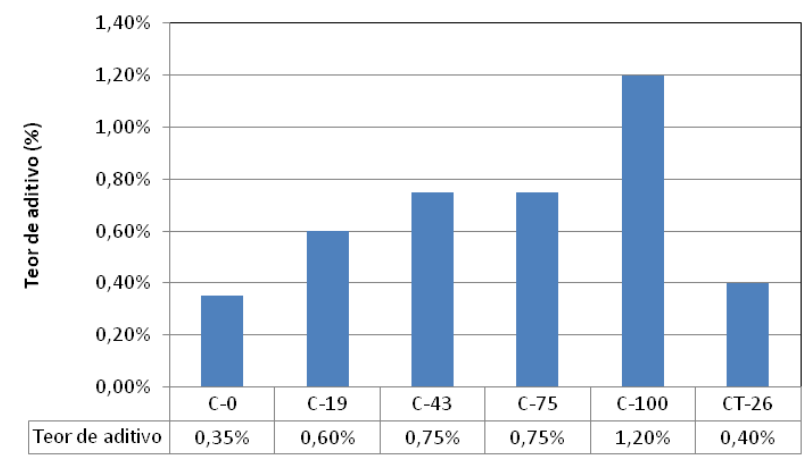

[c]

FIGURA 9: [a] Massa específica, [b] teor de ar e [c] teor de aditivo nos traços analisados. 
O ajuste no teor de aditivo é necessário devido à maior absorção do agregado reciclado, que retira parte da água disponível durante a mistura do concreto, e ao fato de se desejar manter constante a relação água/cimento entre os traços analisados para comparação da resistência mecânica. Trabalhos anteriores realizados com agregados reciclados de estruturas de concreto (LIN et al., 2004) mostraram grande variação no abatimento do traço - de 50 a $180 \mathrm{~mm}$ - quando não é utilizado um aditivo superplastificante no controle da trabalhabilidade do concreto. Neste caso, os autores analisaram traços com relação água/cimento igual a 0,5, variando o teor de agregado graúdo e miúdo reciclados e o tratamento superficial do agregado graúdo. Já outros trabalhos que utilizaram aditivo superplastifcante em teor semelhante ao deste trabalho apresentaram abatimentos de até $240 \mathrm{~mm}$ (PEPE et al., 2014), demonstrando a forte influência da absorção do agregado reciclado na trabalhabilidade do concreto.

A massa específica do concreto sofreu pouca influência com o aumento do teor de substituição do agregado natural pelo agregado reciclado, apresentando redução de no máximo 4\% no seu valor (Figura 9). Isso era de se esperar, tendo em vista que a massa específica do agregado reciclado era apenas 3\% inferior a do agregado graúdo natural. Já o teor de ar da mistura aumentou com o teor de substituição, porém permaneceu abaixo de 3\% (Figura 9), valor máximo admitido neste trabalho para não incorrer em redução da resistência mecânica do concreto. Esse comportamento se deve à maior porosidade dos agregados reciclados quando comparado com os agregados naturais.

O traço C-75 apresentou abatimento maior que os demais, sem uma explicação clara desse fenômeno. Consequentemente, ele apresentou menor massa específica, porém o teor de ar se manteve próximo ao obtido no traço com $100 \%$ de substituição.

Os traços C-19 e CT-26 apresentaram teor de substituição semelhante, porém no traço CT-26 foi utilizado o agregado reciclado tratado.

Comparando as propriedades do concreto no estado fresco entre esses dois traços, observase comportamento semelhante, tanto do ponto de vista da massa específica quanto do abatimento e do teor de ar. A diferença entre eles está no consumo de aditivo, que no traço CT-26 foi de $0,4 \%$ e no traço C-19 foi de 0,6\%. Esse menor consumo de aditivo se deve à menor absorção do agregado reciclado tratado, logo com maior quantidade de água disponível na mistura.

\subsection{PROPRIEDADES DO CONCRETO NO ESTADO ENDURECIDO}

Foram moldados corpos de prova cilíndricos de concreto nas dimensões de $\quad 10$ $\mathrm{cm} \times 20 \mathrm{~cm}$, os quais foram ensaiados para determinação da resistência à compressão, e corpos de prova cilíndricos de concreto nas dimensões de $15 \mathrm{~cm} \times 30 \mathrm{~cm}$, que foram ensaiados para determinação da resistência à tração por compressão diametral e módulo de elasticidade estático. Os resultados estão apresentados na Tabela 5.

TABELA 5: Propriedades do concreto no estado endurecido.

\begin{tabular}{cccccc} 
& Substituição (\%) & $\mathbf{f}_{\mathbf{c m}, \mathbf{j}=\mathbf{7}}$ (MPa) & $\mathbf{f}_{\mathbf{c m}, \mathbf{j}=\mathbf{2 8}}$ (MPa) & $\mathbf{f}_{\mathbf{c t m}, \mathbf{s p}, \mathbf{j}=\mathbf{2 8}(\mathbf{M P a})}$ & $\mathbf{E}_{\mathrm{c}, \mathbf{j}=\mathbf{2 8}}(\mathbf{G P a})$ \\
\hline C-0 & 0 & $26,95 \pm 4,02$ & $36,39 \pm 1,56$ & $3,88 \pm 0,12$ & $29,86 \pm 1,00$ \\
C-19 & 19 & $33,97 \pm 1,39$ & $41,23 \pm 0,59$ & $3,95 \pm 0,02$ & $28,04 \pm 0,06$ \\
C-43 & 43 & $32,79 \pm 3,55$ & $39,60 \pm 1,98$ & $3,63 \pm 0,41$ & $28,04 \pm 0,56$ \\
C-75 & 75 & $29,34 \pm 1,52$ & $35,79 \pm 0,48$ & $3,66 \pm 0,09$ & $26,34 \pm 0,91$ \\
C-100 & 100 & $28,77 \pm 1,38$ & $38,30 \pm 1,07$ & $3,60 \pm 0,18$ & $28,15 \pm 0,88$ \\
CT-26 & 26 & $32,75 \pm 1,70$ & $37,82 \pm 1,39$ & $3,79 \pm 0,05$ & $27,83 \pm 0,48$ \\
\hline
\end{tabular}

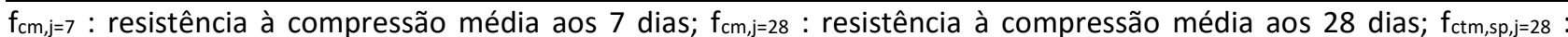
resistência à tração média por compressão diametral aos 28 dias; $\mathrm{E}_{\mathrm{c}, \mathrm{j}=28}$ : módulo de elasticidade estático médio aos 28 dias. 


\subsubsection{RESISTÊNCIAS À COMPRESSÃO E A TRAÇÃO}

Analisando a resistência à compressão média aos 7 dias $\left(f_{c m, j}=7\right)$, observa-se da Tabela 5 que essa resistência alcançou $75 \%$ da resistência aos 28 dias para o traço de referência e para o traço com $100 \%$ de agregados reciclados (C-100). Nos demais traços, essa resistência foi igual, em média, a $83 \%$ da resistência aos 28 dias. Isso sugere um efeito favorável da água absorvida pelo agregado graúdo durante a mistura que posteriormente pode ser liberada, promovendo uma cura interna do concreto. Isso pode auxiliar na velocidade do processo de hidratação dos compostos do cimento.

Analisando a resistência à compressão média aos 28 dias $\left(f_{c m, j}=28\right)$, observa-se da Tabela 5 que o traço de referência apresentou uma menor resistência. Com a substituição de 19\% do agregado natural pelo agregado reciclado, observa-se um aumento na resistência à compressão quando comparado ao traço de referência. Esse aumento pode ser devido à redução da relação a/c (água e cimento), pois o agregado reciclado retém a água da mistura, por ter uma maior absorção de água quando comparado ao agregado natural, liberando-a gradualmente durante o processo de cura do concreto. Com o aumento do teor de substituição até $75 \%$, observase uma redução da resistência à compressão, seguido de um aumento no traço com $100 \%$ de substituição do agregado natural pelo agregado reciclado. $\mathrm{O}$ traço $\mathrm{CT}-26$, com o agregado reciclado tratado, apresentou, em média, uma resistência à compressão próxima a do traço de referência e menor que a dos traços com o agregado reciclado sem tratamento.

Para confirmar se de fato o teor de substituição do agregado natural pelo agregado reciclado afetou as propriedades mecânicas do concreto, foi realizado um teste de comparações múltiplas de médias nos resultados da Tabela 5, utilizando o teste de Tukey com intervalo de confiança de $95 \%$. Na Figura 10 são mostrados os resultados dessa análise.

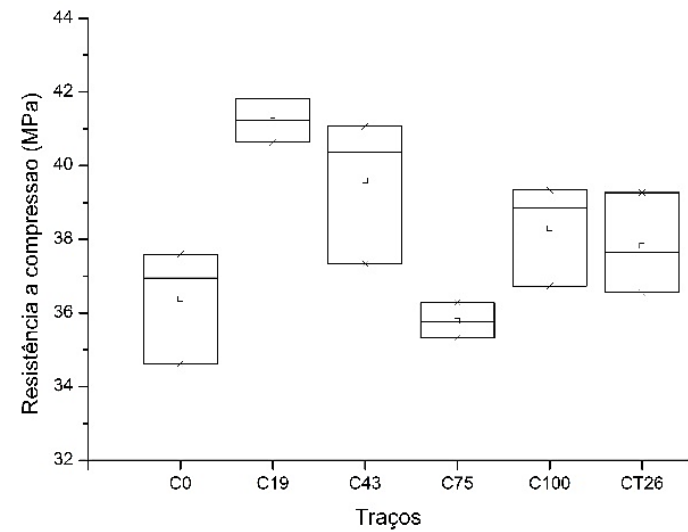

[a]

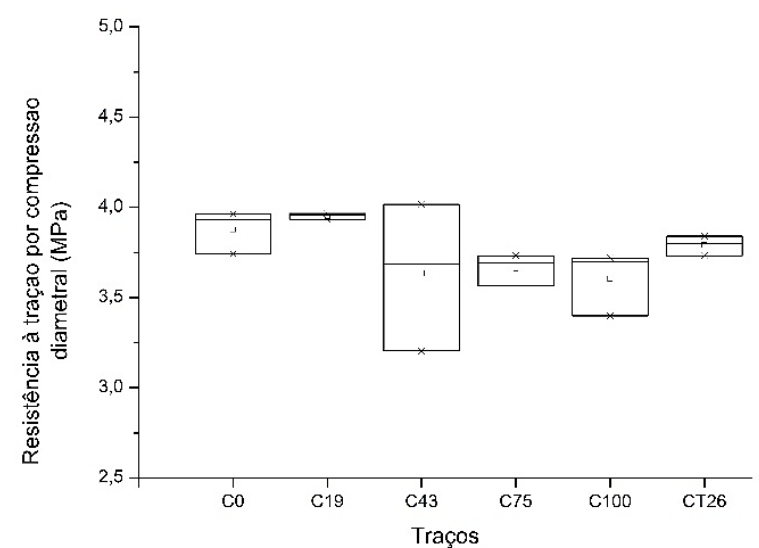

[b]

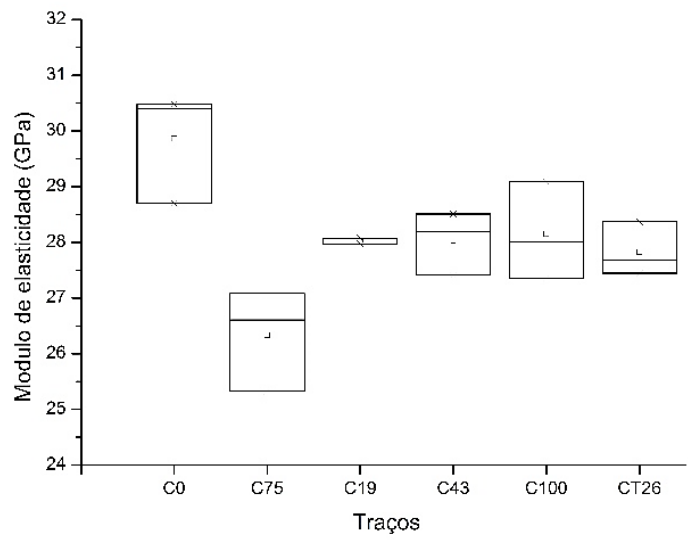

[c]

FIGURA 10: Diagramas de caixa: [a] resistência à compressão; [b] resistência à tração por compressão diametral; [c] módulo de elasticidade. 
Analisando os resultados de resistência à compressão aos 28 dias (Figura 10a), o teste de comparação de médias indica que elas são estatisticamente diferentes, porém não se formam grupos claros. As diferenças significativas devem-se aos traços C-19 e C-75 que apresentaram a maior e a menor resistência, respectivamente, com diferença média de $16 \%$. Os demais traços com agregados reciclados apresentaram média estatisticamente igual ao traço de referência (inclusive o traço C-75), de modo que se conclui que os vários teores de substituição dos agregados naturais pelos agregados reciclados não promoveram alteração significativa da resistência à compressão.

Resultado semelhante foi encontrado por Pepe et al. (2014) para concretos com $100 \%$ de agregados reciclados tratado. Neste caso, a redução da resistência à compressão observada aos 60 dias foi de apenas 9\% quando comparado ao traço de referência com agregados naturais. Já os traços com $100 \%$ de agregados reciclados bruto apresentaram redução na resistência de até $20 \%$. De forma semelhante, Cabral et al. (2010) observaram redução de $10 \%$ e $19 \%$ na resistência à compressão devido à substituição de 50\% e 100\%, respectivamente, dos agregados graúdos naturais por agregados graúdos reciclados oriundos da reciclagem de concretos.

O teste de comparação de médias dos resultados de resistência à tração por compressão diametral (Figura 11b) mostrou que todos os traços formam um único grupo. Logo, conclui-se que a substituição dos agregados naturais pelos agregados reciclados também não promoveu redução significativa da resistência à tração do concreto. Vale ressaltar que Pepe et al. (2014) conseguiram resultado semelhante apenas quando foram empregados agregados reciclados tratados, observando redução de até $13 \%$ quando foram empregados agregados reciclados brutos.

Esses resultados mostram, para o traço em estudo, que é possível realizar a substituição de até $100 \%$ do agregado natural pelo agregado reciclado bruto e ainda assim obter um concreto estrutural com resistência semelhante ao do concreto de referência. Esse resultado difere de trabalhos anteriores que mostraram redução de até $20 \%$ na resistência à compressão devido à completa substituição do agregado natural pelo agregado graúdo reciclado no seu estado bruto (CABRAL et al., 2010; PEPE et al., 2014). Por essa razão, alguns trabalhos sugerem que a substituição ótima dos agregados graúdos naturais por agregado reciclados é de apenas $42 \%$ (LIN et al., 2004). Tal diferença com relação a esses trabalhos se deve, em grande parte, à qualidade do agregado reciclado bruto utilizado na presente pesquisa, que praticamente não possuía resíduos cerâmicos e uma massa específica superior a dos agregados reciclados utilizados nos trabalhos citados.

Na Figura 11 é mostrada foto dos corpos de prova com substituição de $100 \%$ dos agregados naturais pelos agregados reciclados após o ensaio de compressão diametral, das quais se nota que praticamente não há resíduos cerâmicos nos corpos de prova. Além disso, é possível notar que mesmo no traço com $100 \%$ de agregados reciclados ainda se observa a presença de uma quantidade razoável de agregados graúdos.

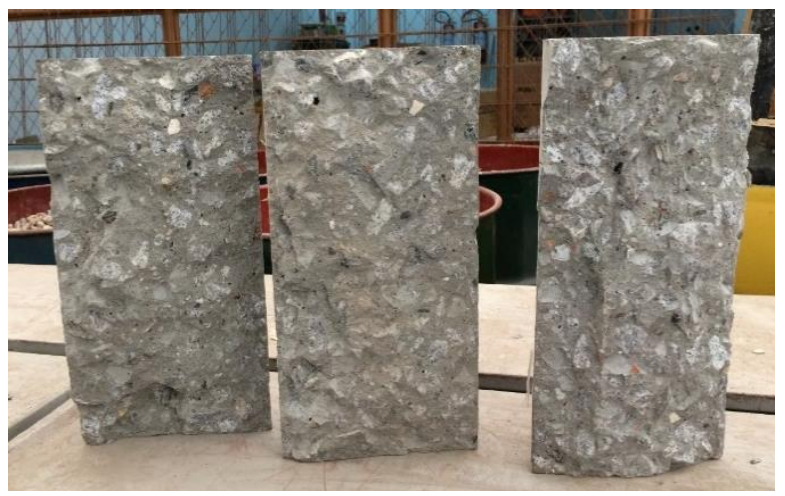

FIGURA 11: Aspecto dos corpos de prova após o ensaio de compressão diametral.

\subsubsection{MÓDULO DE ELASTICIDADE}

Com relação ao módulo de elasticidade (Figura 10c), os resultados do teste de comparações múltiplas de médias, com o teste de Tukey, indicam a formação de três grupos distintos, isto é: traço $\mathrm{C}-0$, traço $\mathrm{C}-75 \mathrm{e}$ traços C-19, C-43, C-100 e CT-26. Isso comprova que o módulo de elasticidade foi influenciado pela substituição do agregado natural pelo agregado 
reciclado bruto, apresentando redução média de $6 \%$ a $12 \%$ com relação ao traço de referência. Entretanto, não é possível afirmar que o teor de substituição tenha influenciado o valor do módulo de elasticidade, sendo que apenas o traço C-75 mostrou-se significativamente diferente dos demais traços com agregados reciclados.

Já o traço CT-26, com o agregado reciclado tratado, teve a sua média estatisticamente no mesmo grupo dos traços com o agregado reciclado não tratado. Daí pode-se concluir que, neste trabalho, o tratamento do agregado reciclado não foi capaz de evitar a diminuição do módulo de elasticidade do traço de referência.

Resultados divergentes são encontrados na literatura. Por exemplo, Pepe et al. (2014) não encontraram variação significativa no valor do módulo de elasticidade quando $100 \%$ dos agregados naturais são substituídos por agregados reciclados - brutos ou tratados. Já Cabral et al. (2010) observaram redução de $11 \%$ e $21 \%$ no valor do módulo de elasticidade devido à substituição de $50 \%$ e $100 \%$, respectivamente, dos agregados graúdos naturais por agregados graúdos reciclados oriundos da reciclagem de concretos. De certa forma, é difícil determinar uma correlação entre os resultados dessas diferentes pesquisas, uma vez que tanto o volume de agregados graúdos no traço quanto a composição mineralógica desses agregados variaram nas diferentes pesquisas.

Os resultados da presente pesquisa permitem afirmar que, para o traço analisado, é possível realizar a substituição de até $100 \%$ do agregado natural pelo agregado reciclado sem redução significativa do módulo de elasticidade do concreto, o que se deve à qualidade do agregado reciclado bruto utilizado, principalmente em relação ao teor de agregados naturais presentes no agregado reciclado.

\section{CONCLUSÃO}

Com base nos resultados obtidos pode-se concluir que:

- É possível a substituição de $100 \%$ do agregado natural pelo agregado reciclado de construção e demolição sem prejuízo das resistências à compressão e à tração do concreto, apesar das normas brasileiras ainda não permitirem essa substituição para concretos com fins estruturais. Os concretos com vários teores de substituição apresentaram valores de resistências a compressão e a tração que não se diferiram significativamente dos valores do traço de referência. Para garantir esse comportamento, é fundamental a adequada seleção dos resíduos que darão origem ao agregado reciclado. Recomenda-se agregados reciclados com baixo teor de resíduos cerâmicos e com massa específica maior que $2,5 \mathrm{~kg} / \mathrm{dm}^{3}$.

- O módulo de elasticidade foi influenciado pela substituição do agregado natural pelo agregado reciclado, porém essa influência foi pouco significativa. Nesse caso, a redução observada no valor do módulo de elasticidade variou de $6 \%$ a $12 \%$

- O tratamento mecânico realizado para limpar o agregado reciclado resultou em uma recuperação de cerca de $53 \%$ de agregados de melhor qualidade. Estes apresentavam maior massa específica e menor absorção que os agregados reciclados brutos que vieram da indústria, o que resultou em um menor consumo de aditivo quando comparado aos traços com agregado reciclado bruto. Entretanto, após o tratamento, eles apresentavam uma composição granulométrica próxima de uma Brita 0 e com deficiência de distribuição entre os grãos. Por essa razão, o teor de substituição ficou em apenas 26\%, uma vez que se procurou manter constante o módulo de finura dos agregados. Ao final, o traço com esse agregado apresentou resistência mecânica (compressão e tração) igual ao do traço de referência, porém apresentou uma redução de $7 \%$ no valor do módulo de elasticidade. Isso sugere que outros testes deverão ser realizados com esse agregado, com outros teores de substituição, de modo a confirmar esses resultados. 
A principal contribuição desta pesquisa é mostrar a possibilidade da confecção de concretos com finalidade estrutural e com até $100 \%$ de agregados graúdos reciclados. Para isso, é necessário garantir a qualidade dos agregados reciclados, o que pode ser realizado pelo controle da massa específica do agregado reciclado.

\section{AGRADECIMENTOS}

Os autores agradecem a empresa RNV Resíduos pela doação dos agregados reciclados utilizados na pesquisa, bem como a empresa Mold - Estruturas Pré-moldadas pela doação do aditivo utilizado e a empresa EBM Incorporação S.A. pela doação do cimento. Agradecem, ainda, aos técnicos Danielle, Valdivino e Victor que auxiliaram na realização dos ensaios.

\section{REFERÊNCIAS BIBLIOGRÁFICAS}

ANGULO, S. C. Caracterização de agregados de resíduos de construção de demolição reciclados e a influência de suas características no comportamento de concretos. 2005. 236 f. Tese (Doutorado em Eng. Civil) - Escola Politécnica, Universidade de São Paulo, SP, 2005.

AREZOUMANDI, M.; DRURY, J.; VOLZ, J. S.; KHAYAT, K. H.. Effect of Recycled Concrete Aggregate Replacement Level on Shear Strength of Reinforced Concrete Beams. ACI Materials Journal, V. 112, No. 4, p. 559-567, 2015.

ASSOCIAÇÃO BRASILEIRA DE NORMAS TÉCNICAS. NBR 9776: Agregados - Determinação da massa específica de agregados miúdos por meio do frasco Chapman Método de ensaio. Rio de Janeiro, 1987, 3 p.

NM 67: Concreto - Determinação da consistência pelo abatimento do tronco de cone. Rio de Janeiro, 1998, 8 p.

.. NM 51: Agregado graúdo - Ensaio de abrasão "Los Ángeles". Rio de Janeiro, 2001, 6 p.

.. NM 47: Concreto - Determinação do teor de ar em concreto fresco - Método pressométrico. Rio de Janeiro, 2002, 23 p.

NBR 5738: Concreto - Procedimento para moldagem e cura de corpos-de-prova. Rio de Janeiro, 2003, 6 p.
.. NBR NM 248: Agregados - Determinação da composição granulométrica. Rio de Janeiro, 2003, 6 p.

.. NBR 5739: Concreto - Ensaios de compressão de corpos-de-prova cilíndricos. Rio de Janeiro, 2007, 9 p.

.. NBR 8522: Concreto - Determinação do módulo estático de elasticidade à compressão. Rio de Janeiro, 2008, 16 p.

NM 53: Agregado graúdo - Determinação da massa específica, massa específica aparente e absorção de água. Rio de Janeiro, 2009, 8 p.

NBR 7211: Agregados para concreto Especificação. Rio de Janeiro, 2009, 9 p.

NBR 7222: Concreto e argamassa Determinação da resistência à tração por compressão diametral de corpos de prova cilíndricos. Rio de Janeiro, 2011, 5 p.

ASTM INTERNATIONAL. ASTM C1231 / C1231M-14. Standard Practice for Use of Unbonded Caps in Determination of Compressive Strength of Hardened Concrete Cylinders. West Conshohocken, PA, 2014.

BLUMENSCHEIN, R. N. Manual Técnico: Gestão de Resíduos Sólidos em Canteiro de Obras. Brasília: Serviço Brasileiro de Apoio as Micro e Pequenas Empresas SEBRAE/DF. 2007.48 p.

BLUMENSCHEIN, R. N. Programa de Redução de Desperdício e Gestão de Materiais. In: Prêmio CREA Goiás de Meio Ambiente - Compêndio dos trabalhos premiados. 2003. Goiânia: Safra Gráfica e Editora Ltda, 2004. p. 87-117.

CABRAL, A. E. B.; SCHALCH, V.; DAL MOLIN, D. C. C.; RIBEIRO, J. L. D. Mechanical properties modeling of recycled aggregate concrete. Construction and Building Materials, Vol. 24, p. 421-430, 2010.

CABRAL, A. E. B.; SCHALCH, V.; DAL MOLIN, D. C. C.; RIBEIRO, J. L. D. Performance Estimation for Concretes Made with Recycled Aggregates of Construction and Demolition Waste of Some Brazilian Cities. Materials Research, Vol. 15, No. 6, p. 1037-1044, 2012.

CARRIJO, P. M. Análise da influência da massa específica de agregados graúdos provenientes de resíduos de construção e demolição no desempenho mecânico do concreto. 2005. 146 f. Tese (Mestrado em Engenharia Civil) - Escola Politécnica, Universidade de São Paulo, São Paulo, 2005.

CONSELHO NACIONAL DO MEIO AMBIENTE-CONAMA. Resolução 307. Estabelece diretrizes, critérios e procedimentos para a gestão dos resíduos da 
construção civil, 2002. Disponível em < http://www.mma.gov.br/port/conama/legiabre.cfm?co dlegi=307 >. Acesso em 01 de Abril de 2014.

CONSELHO NACIONAL DO MEIO AMBIENTE-CONAMA. Resolução 448. Altera os arts. 2ㅇ, 4ㅇ, 5ㅇ, 6ㅇ, 8ㅇ, 9ㅇ, 10 e 11 da Resolução no 307, de 5 de julho de 2002, do Conselho Nacional do Meio Ambiente-CONAMA, 2012. Disponível em http://www.mma.gov.br/port/conama/legiabre.cfm?co dlegi=672 >. Acesso em 01 de Abril de 2014.

KANG, T. H. K.; KIM, W.; KWAK, Y. K.; HONG, S. G.. Flexural Testing of Reinforced Concrete Beams with Recycled Concrete Aggregates. ACl Structural Journal, Vol. 111, No. 3, p. 607-616, 2014.

LIMA, J. A. R. Proposição de diretrizes para produção e normalização de resíduo de construção reciclado e de suas aplicações em argamassas e concretos. 1999. 246 f. Dissertação (Mestrado em Arquitetura e Urbanismo) Escola de Engenharia de São Carlos, Universidade de São Paulo, São Carlos, 1999.

LIN, Y; TYAN, Y; CHANG, T; CHANG, C. An assessment of optimal mixture for concrete made with recycled concrete aggregates. Cement and Concrete Research, Vol. 34, p. 1373-1380, 2004.

MEHTA, P. K.; MONTEIRO, P. J. M.. Concreto Microestrutura, Propriedades e Materiais. 3 ed. São Paulo: Ibracon, 2008. 674 p.

PACHECO, J.; BRITO, J.; FERREIRA, J.; SOARES, D.. Destructive Horizontal Load Tests of Full-Scale Recycled-Aggregate Concrete Structures. ACI Structural Journal, V. 112, No. 6, p. 815-826, 2015.

PEPE, M; TOLEDO FILHO, R. D.; KOENDERS, E. A. B.; MARTINELLI, E. Alternative processing procedures for recycled aggregates in structural concrete. Construction and Building Materials, V. 69, p. 124-132, 2014.

PINTO, T. P. Metodologia para a gestão diferenciada de resíduos sólidos da construção urbana. 1999. 189 f. Tese (Doutorado em Engenharia de Construção Civil) - Escola Politécnica, Universidade de São Paulo, São Paulo, 1999.

RAHAL, K. N.; AL-KHALEEFI, A. L.. Shear-Friction Behavior of Recycled and Natural Aggregate Concrete-An Experimental Investigation. ACl Structural Journal, V. 112, No. 6, p. 725-733, 2015.
REZENDE, C. L.; FARIAS, M. M.; SILVA, R. C. S. Produção Mais Limpa, Redução e o Reaproveitamento dos Resíduos de Construção e Demolição (RCD). In: VII CONGRESSO NORTE NORDESTE DE PESQUISA E INOVAÇÃO, 2012, Palmas, Tocantins. Anais... [s.I.], [s.n.], [2012]. 8 p.

SIKA. Ficha do produto. Sika ViscoCrete Precast. Disponível em < http://bra.sika.com/dms/getdocument.get/e12cdbe67359-3b69-b3da-

b12d63825e44/Sika\%20ViscoCrete\%20Precast.pdf >. Acesso em 27 de Setembro de 2014.

TENÓRIO, J. J. L. Avaliação de propriedades do concreto produzido com agregados reciclados de resíduos de construção demolição visando aplicações estruturais. 2007. 138 f. Dissertação (Mestrado em Engenharia Civil) - Universidade Federal de Alagoas, Maceió, 2007.

YANG, K. H.; CHUNG, H. S.; ASHOUR, A. F. Influence of Type and Replacement Level of Recycled Aggregates on Concrete Properties. ACI Materials Journal, V. 105, No. 3, p. 289-296, 2008. 